\title{
Factors associated to the length of time on mechanical ventilation in the postoperative period of cardiac surgery
}

\author{
Fatores associados ao tempo de ventilação \\ mecânica no pós-operatório de cirurgia cardíaca \\ Factores asociados con el retraso en la extubación \\ endotraqueal en el postoperatorio de cirugía cardíaca
}

\author{
Laura Fonseca ${ }^{a}$ \\ Fernando Nataniel Vieirab \\ Karina De Oliveira Azzolinc
}

D0l: $\quad$ http://dx.doi.org/10.1590/19831447.2014.02.44697

\footnotetext{
a Nurse, graduated at the Federal University of Rio Grande do Sul (UFRGS), Porto Alegre-RS, Brazil

${ }^{b}$ Physiotherapist, Clinical Hospital of Porto Alegre and Nossa Senhora da Conceição Hospital, Porto Alegre-RS, Brazil.

' Doctorate in Nursing from the Federal University of Rio Grande do Sul (UFRGS), Assistant Professor at the School of Nursing and of the Post Graduate Programme in Nursing at UFRGS, Porto Alegre-RS, Brazil.
}

\section{ABSTRACT}

Our objective was to identify factors associated with the duration of mechanical ventilation (MV) postoperative to cardiac surgery and assess the association between duration of endotracheal intubation, length of stay in the Intensive Care Unit (ICU) and hospital. Longitudinal, retrospective study of medical records of 116 adults undergoing cardiac surgery from March 2012 to May 2013. The mean age was $57 \pm 14$ years, predominantly male and coronary artery bypass grafting surgery $(52.6 \%)$. The MV time was $15.25(7.66$ to 23.68) hours. Associated with longer MV was the age $(r=0.5, p<0.001)$, comorbidities $(r=0.344, p<0.001)$, cardiopulmonary bypass time $(r=0.244, p=0.008)$, duration of continuous sedation $(r=0.607, p<0.001)$, sedative doses $(r=0.4, p<0.001)$, time of vasoconstrictors and vasodilators $(r=0.711, p<0.001, r=0.368, p<0.001)$, drainage of the 1st time $(r=0.201, p<0.031)$, presence of drains $(r=0.445, p<0.001)$, postoperative complications $(r=0.524, p<0.001)$ and hospital stay. Our data confirms that both preoperative, transoperative and postoperative variables prolong the VM and therefore the hospital stay.

Descriptors: Thoracic surgery. Airway extubation. Artificial Respiration. Postoperative complications. Perioperative nursing.

\section{RESUMO}

Nosso objetivo foi identificar fatores associados ao tempo de ventilação mecânica (VM) no pós-operatório de cirurgia cardíaca e verificar associação entre tempo de entubação endotraqueal, tempo de internação na Unidade de Terapia Intensiva (UTI) e hospitalar. Estudo longitudinal, retrospectivo com 116 prontuários de adultos submetidos à cirurgia cardíaca no período de março 2012 a maio 2013. A média de idade foi $57 \pm 14$ anos; houve predomínio do sexo masculino e de cirurgia de revascularização do miocárdio (52,6\%). 0 tempo VM foi 15,25 (7,66-23,68) horas. Foram relacionadas com maior tempo em VM a idade $(r=0,5 ; p<0,001)$, comorbidades $(r=0,344 ; p<0,001)$, tempo de circulação extracorpórea $(r=0,244 ; p=0,008)$, tempo de sedação contínua $(r=0,607 ; p<0,001)$, doses sedativas ( $r=0,4 ; p<0,001)$, tempo de vasoconstritores e vasodilatadores $(r=0,711 ; p<0,001 ; r=0,368 ; p<0,001)$, drenagem da 1a hora $(r=0,201 ; p<0,031)$, permanência dos drenos $(r=0,445 ; p<0,001)$, complicações do pós-operatório $(r=0,524 ; p<0,001)$ e permanência hospitalar. Nossos dados confirmam que tanto variáveis pré, trans e pós-operatórias prolongam o tempo de VM e, consequentemente, a permanência hospitalar.

Descritores: Cirurgia torácica. Extubação. Respiração artificial. Complicações pós-operatórias. Enfermagem perioperatória.

\section{RESUMEN}

Nuestro objetivo fue identificar los factores asociados con la duración de la ventilación mecánica (VM) en postoperatorio de cirugía cardiaca y evaluar la asociación entre la duración de la intubación endotraqueal, la duración de la estancia en la Unidad de Cuidados Intensivos (UCI) y el hospital. Estudio longitudinal, retrospectivo con una muestra de 116 adultos sometidos a cirugía cardíaca de marzo 2012 a mayo 2013. La edad media fue de 57士14 años, predominio masculino y la realización de revascularización coronaria (52,6\%). El tempo de VM fue 15,25 (7,66 a 23,68) horas. Se asociaron con una mayor edad MV $(r=0,5, p<0,001)$, la comorbilidad $(r=0,344, p<0,001)$, el tiempo de circulación extracorpórea $(r=0,244, p=0,008)$, la duración de la sedación continua $(r=0,607, p<0,001)$, las dosis sedantes $(r=0,4, p<0,001)$, el tiempo de vasoconstrictores y vasodilatadores $(r=0,711$, $p<0,001, r=0,368, p<0,001)$, el drenaje del primer tiempo $(r=0,201, p<0,031)$, la presencia de drenajes $(r=0,445, p<0,001)$, las complicaciones postoperatorias $(r=0,524, p<0,001)$ y la estancia hospitalaria. Nuestros datos confirman que tanto variables pre y postoperatorias prolongan el tiempo de VM y, por lo tanto, la estancia en el hospital.

Descriptores: Cirugía torácica. Extubación traqueal. Respiración artificial. Complicaciones postoperatorias. Enfermería perioperatoria. 


\section{口INTRODUCTION}

Cardiac surgeries for myocardial revascularization and repair or valve replacement are considered major surgeries with intensive care needs during the immediate postoperative period. Despite all the advances in technology, complications during the postoperative period of these surgeries are still significant and of high incidence ${ }^{(1)}$.

After cardiac surgery the patient is usually taken directly to the Surgical Intensive Care Unit (ICU). There they stay on mechanical ventilation until not only until consciousness is reestablished, but also their condition: cardiovascular, ventilatory, renal and metabolism, which may be unbalanced and need to be adjusted during the first few hours, avoiding any major impact due to complications. However in some cases complications can occur due to the surgical procedure and/or clinical condition of the patient raising the possibility of a longer time on mechanical ventilation $(\mathrm{MV})$ in the $\mathrm{ICU}^{(2)}$.

Pulmonary complications in patients who were submitted for heart surgery is approximately $57 \%$ of the total of complications ${ }^{(3)}$, this data varies in studies from between $10 \%$ to $60 \%$ in the postoperative period of cardiac surgery ${ }^{(4)}$.

Keeping in place the endotracheal tube (ETT) results in a longer stay in the ICU and the hospital, increasing costs and the necessity of personnel and material resources ${ }^{(2-3)}$. Therefore it is necessary for a nurse to participate with the health team in the decision on the ideal moment for extubation and the removal from MV, based on the previous medical report of the individual and preoperative and transoperative data.

The factors which are contribute to respiratory complications are: age, previous illness surgical incision, general anaesthesia, cardiopulmonary bypass (CPB), duration of ischemia, surgical approach, surgical manipulation and the number of pleural drains. As a consequence there could be a reduction in the pulmonary volume and capacity, change in the exchange of gases in relation to ventilation/perfusion and mechanical ventilation ${ }^{(4-6)}$ and these could mean a delay in the extubation of the surgical patients.

Endotracheal extubation, defined as the removal of ETT, is recommended in the first few hours of the postoperative period, preferably before the sixth hour of arriving in the $I C U^{(7)}$. It is considered a prolongation of the endotracheal intubation - extubation delay - delaying ETT from 6 to 48 hours after the surgery, and can result in possible postoperative complications, relating to invasive procedures ${ }^{(2,4-6)}$.

This study has the objective of identifying the factors associated with the length of time that patients are on MV during the postoperative period of cardiac surgery and moreover to verify the association between time of endotracheal intubation and internment time in the ICU and hospital.

\section{METHODS}

It is a retrospective study ${ }^{(8)}$ of long term planning, with patients who underwent cardiac surgery from march 2012 through to may 2013 in a hospital located in Porto Alegre/ RS. The sample includes 118 medical records from patients who had cardiac surgery with the use of CPB, for both genders over 18 years old, with external approach and internment in ICU with the necessity for MV. From these two medical records were excluded due to insufficient data.

The collection of data was retrospectively made through a search of data in the physical and digital medical records of the subjects targeted by the study, conforming to the inclusion and exclusion criteria using a specific instrument. We searched for pre, trans and postoperative data associated with long term MV and patient internment in the ICU and hospital. The data referred to the period that the patient was on MV.

The data was digitalized and inputted into a data package called Microsoft Excel 2007 and analysed by the Statistical Package for Social Sciences (SPSS v. 18). The normal parameters of the data were established using the Kolmogorov-Smirnov test. Continuous variables were described as median and interquartile range (25-75) for non-parametric data; and as mean and standard deviation for parametric data. We used the Spearman test of correlation for the length of stay in MV in the postoperative period of cardiac surgery and the other continuous variables. The categorical variables were described as absolute numbers and percentages. The duration on MV in relation to categorical variables were analysed from the difference between medians by applying the $U$ test of Mann Whitney. Two-tailed $p<0.05$ was considered statistically significant.

The study was approved by the Ethics Committee in Research of the Federal University of Rio Grande do Sul UFRGS ( $n^{\circ} .384 .889$ ) and by the institution where the research took place (n०. 406.229). In all medical records used was annexed a copy of the Terms for the Use of Data and its information only will be disclosed anonymously.

\section{口RESULTS}

A total of 116 medical records, of patients who underwent cardiac surgery were assessed, the majority male with an average age of 57 and from the capital, Porto Alegre. Other sample characteristics are described in Table 1. 
All the patients submitted to cardiac surgery stayed with MV during the postoperative period, the median time of MV for the study people was 15.25 (7.66-23.68) hours.

The surgical variables of trans and postoperative associated with time of MV are described in Table 2.

Complications were analysed during the period that ETT was maintained during the postoperative period, identifying the time of MV in their presence and absence. The data shows that patients who had complications, stayed longer on MV. These results are described in Table 3.

The complications due to acute myocardial infarction $(p=0.114)$, cerebral vascular accident/stroke $(p=0.061)$, arrhythmias $(p=0.064)$ and reoperation $(p=0.08)$ haven't shown important statistical significance, when analysed individually.

The increase in time on $\mathrm{MV}$ is still associated to age $(r=0.5 ; p<0.001)$, systemic arterial hypertension $(p=0.005)$, chronic obstructive pulmonary disease $(p=0.015)$ and chronic renal failure $(p=0.009)$. It is also significantly related to a longer stay in the ICU $(r=0.5 ; p<0.001)$, and in the hospital ( $r=0.3 ; p=0.002)$, but the correlations are moderate and respectively weak.

\section{口DISCUSSION}

The results identified pre, trans and postoperative variables associated with a patients longer stay under MV.

Among the clinical preoperative variables, there are: chronic obstructive pulmonary disease, systemic arterial hypertension, chronic renal failure, great number of associated comorbidies and also surgical variables regarding the long time undergoing $C P B$, use of sedative and analgesic drugs,
Table 1. Socio-clinical demographic characteristics from the sample $(\mathrm{N}=116)$

\begin{tabular}{|c|c|}
\hline Variables & $N(\%)$ \\
\hline $\begin{array}{l}\text { Gender } \\
\text { Male }\end{array}$ & 75(64.7) \\
\hline Age $^{*}$ (years) & $57 \pm 14$ \\
\hline $\begin{array}{l}\text { Where from } \\
\text { Great Porto Alegre } \\
\text { Porto Alegre } \\
\text { Outside the city }\end{array}$ & $\begin{array}{c}55(47.4) \\
36(31) \\
25(21.6)\end{array}$ \\
\hline $\begin{array}{l}\text { Co-morbid conditions } \\
\text { Systemic Arterial Hypertension } \\
\text { Ischemic Heart } \\
\text { Smoke } \\
\text { Diabetes Mellitus } \\
\text { Dyslipidemia } \\
\text { Neuropathies } \\
\text { Chronic obstructive pulmonary disease } \\
\text { Chronic renal failure }\end{array}$ & $\begin{array}{c}79(68.1) \\
68(58.6) \\
41(35.3) \\
36(31) \\
31(26.7) \\
13(11.2) \\
5(4.3) \\
3(2.6)\end{array}$ \\
\hline $\begin{array}{l}\text { Surgery types } \\
\text { Coronary artery bypass graft } \\
\text { Valve replacement } \\
\text { Coronary artery bypass graft + Valve } \\
\text { Congenital Heart Disease } \\
\text { Others }\end{array}$ & $\begin{array}{c}61(52.6) \\
36(31) \\
9(7.8) \\
5(4.3) \\
5(4.3)\end{array}$ \\
\hline Length of stay ${ }^{\dagger}$ (days) & $27(18-36.75)$ \\
\hline
\end{tabular}

Source: Researched data.

*Data presented as mean ( \pm standard deviation), ${ }^{\dagger}$ data presented as medians (interquartiles $25 \%-75 \%$ ).

Tabela 2. Correlation between MV time and surgical variables.

\begin{tabular}{lccc}
\multicolumn{1}{c}{ Variables } & $\begin{array}{c}\text { Median } \\
\mathbf{( 2 5 - 7 5 \% )}\end{array}$ & $\begin{array}{c}\text { Correlation with MV } \\
\text { time length }\end{array}$ & P \\
\hline Time Cardio pulmonary bypass (Min.) & $109(89-138)$ & 0.244 & 0.008 \\
Period of use of vasoconstrictor & $8.1(2-16.5)$ & 0.711 & $<0.001$ \\
Period of use of vasodilator & $1(0-13.9)$ & 0.368 & $<0.001$ \\
Period of continuous use of sedation and analgesia & $0(0-2.5)$ & 0.607 & $<0.001$ \\
Dosage total for sedation and analgesia & $2(1-4)$ & 0.4 & $<0.001$ \\
Drainage volume in the 1st hour (ml) & $100(50-150)$ & 0.201 & 0.031 \\
Length of stay with the drains & $45(40-62)$ & 0.445 & $<0.001$ \\
Total amount of postoperative complications* & $1(0-2)$ & 0.524 & $<0.001$ \\
\hline
\end{tabular}

Source: Research data.

Results expressed in hours with median ( interquatiles 25\%-75\%)

*No variation out of the 11 complications shown. 
Table 3. Length of stay on MV in relation to postoperative complications.

\begin{tabular}{|c|c|c|c|}
\hline Variables & $\mathbf{N}$ & Length of stay (25-75\%) & *p \\
\hline \multicolumn{4}{|l|}{ Use of drug vasoconstrictors } \\
\hline Yes & 92 & $15.87(10.25-39.87)$ & $<0.001$ \\
\hline No & 24 & $8.54(5.62-15.08)$ & \\
\hline \multicolumn{4}{|l|}{ Complications postoperative } \\
\hline Yes & 80 & $16.12(8-60.2)$ & 0,005 \\
\hline No & 36 & $12.75(6.6-15.8)$ & \\
\hline \multicolumn{4}{|l|}{ Acute Renal Failure } \\
\hline Yes & 14 & $101.83(15.5-233.16)$ & $<0.001$ \\
\hline No & 102 & $14.53(7-20.7)$ & \\
\hline \multicolumn{4}{|l|}{ Atelectasis } \\
\hline Yes & 3 & $191.75(93.4-260.3)$ & 0.003 \\
\hline No & 113 & $15.25(7.63-22)$ & \\
\hline \multicolumn{4}{|c|}{ Pneumonia associated with MV } \\
\hline Yes & 15 & $96,83(24-258,58)$ & $<0.001$ \\
\hline No & 101 & $14,66(7-18,6)$ & \\
\hline \multicolumn{4}{|l|}{ Sepsis } \\
\hline Yes & 7 & $258.58(96.8-351)$ & $<0.001$ \\
\hline No & 109 & $15(7.3-21.45)$ & \\
\hline \multicolumn{4}{|l|}{ Metabolic Acidosis } \\
\hline Yes & 54 & $16.9(11.68-74.83)$ & 0.001 \\
\hline No & 62 & $13.9(6.43-16.56)$ & \\
\hline \multicolumn{4}{|l|}{ Encephlopathy post CPB } \\
\hline Yes & 6 & $203.45(65.8-281.68)$ & $<0.001$ \\
\hline No & 110 & $15(7.45-21.35)$ & \\
\hline \multicolumn{4}{|l|}{ Death } \\
\hline Yes & 16 & $95.12(26.6-214.4)$ & $<0.001$ \\
\hline No & 100 & $14.5(7-18.8)$ & \\
\hline
\end{tabular}

Source: Research data.

Results expressed in hours with median (interquatiles 25\%-75\%) CPB:cardiopulmonary bypass. * U de Mann-Whitney's test.

length of use of vasoactive drugs, length of stay with drain tubes and draining volume in the $1^{\text {st }}$ hour after surgery.

Also associated with the length of stay on MV during the postoperative period of cardiac surgery were complications, acute renal failure, atelectasis, pneumonia associated with MV, sepsis, metabolic acidosis, encephalopathy and the sum of all complications.

The age factor showed a directly proportional correlation to the length of stay on MV in the postoperative period of cardiac surgery, and consequently all the incurring complications, a fact this has been noted in many papers ${ }^{(9)}$. Due to the increase of life expectancy, we have more elderly patients who need heart surgery, which reinforces the necessity for qualified care for these patients ${ }^{(9)}$. Allied to age, preoperative comorbidities, such as chronic obstructive pulmonary disease and chronic renal failure are Variables described as potentials for surgical risk in heart surgery ${ }^{(10)}$. When overlaid, they also contribute, in our study, to a longer stay with ETT.

In the transoperative period, the time of CPB influences recovery, being important for the nurse to consider during postoperative ${ }^{(11)}$, since its prolongment can cause pulmonary congestion, damage to the pulmonary vascular endothelium and strength reduction of the ventilatory muscles, causing complications such as hypoxemia and atelectasiss and possibly resulting in the greater need of ventilatory support ${ }^{(12)}$.

A study made by nurses in the postoperative Thoracic Surgery unit compared the frequency of complications 
presented by the patients during immediate postoperative cardiac surgery according to the length of stay in CPB, however the majority of the complications were independent of this time (11). In our study we found an association between the length of time in CPB and a delay in the extubation of the patients - however this last variable wasn't analysed in the article mentioned.

In the postoperative period, there is the need to control pain and anxiety. In a study made by nurses in a specialized cardio hospital, it was identified that these factors generate the need for sedatives and analgesic drugs, consequently depressing levels of consciousness, increasing the length of time of endotracheal intubation ${ }^{(13)}$. This confirms our findings that there is a correlation with continuous or intermittent use of sedatives and analgesic drugs and the time spent on MV in the postoperative period of cardiac surgery.

Thus, the of use of vasoactive drugs is necessary to re-establish a hemodynamic status, and this makes it difficult to wean serious patients with hemodynamic instability off the ventilator ${ }^{(12)}$ and lengthens their stay in the $\mathrm{ICU}^{(3)}$. The length of time using vasoconstrictor and vasodilator drugs reflects the severity of the patients and, in our study, was correlated with a longer stay on MV.

Thus, in the postoperative period of cardiac surgeries, the nursing team need to quantify the extension of thoracic drainage and foresee possible bleeding - being attentive as bleeding is considered an independent mortality predictor and is associated with advert results, such as: length of stay in hospital, internment in ICU, ventilation timing and pneumonia rates, septicaemia, hemofiltration, tracheostomy, re-intubation and re-admission at ICU(14). In our study, the volume of drainage in the postoperative period of cardiac surgery shows a correlation with increase of time on $\mathrm{MV}$, but this correlation seemed more significant with the quantity drained in the 1st hour in the ICU.

Among the postoperative complications, acute renal failure is regarded by some authors as one of the complications with the biggest impact on unfavourable endings ${ }^{(10,15)}$. However the length of time on MV is one of the factors that can lead to the loss of renal function ${ }^{(15)}$. Our results showed that the time of stay on MV was higher in the population who developed this clinical condition. But it is not possible to confirm if the need for more time till ETT induced the development of acute renal failure or vice versa.

In a previous study, sepsis was a very rare complication, and the lungs were the primary focus in the majority of cases $^{(16)}$. Infection is a risk factor which most prevails in the perioperative period, increasing the time of internment and mortality ${ }^{(17)}$. The most prevalent pulmonary complica- tions in our study were pneumonia and atelectasis, both associated with a longer time on $\mathrm{MV}^{(3)}$.

Another complication which influenced the time on MV was metabolic acidosis, because when present it can be an important factor in causing depression of the myocardial function and it is a sensitive indicator of bad tissue perfusion ${ }^{(18)}$

Times of over 105 minutes of CPB is considered a risk factor for encephalopathy during the postoperative period of cardiac surgery ${ }^{(19)}$. Although the average time of CPB is over $105 \mathrm{~min}$ there were only six reported cases of this kind found in medical records studied. Accordingly with the mentioned study ${ }^{(19)}$, there was an association between these complications and a lengthy stay on MV.

The presence of complication in the postoperative period of cardiac surgery increases the length of time on MV, which then is followed by other consequent complications. We have already shown that to extubate these patients, as early as possible (including from the surgery room), can have benefits caused by the following factors: minimize pulmonary injury, cardiac output increase, improves renal perfusion reducing acute renal failure, stress reduction, and ETT breathing discomfort from MV weaning. And furthermore it avoids the need for sedatives, including, being possible to exclude $M V$, reducing internment time and costs ${ }^{(20)}$.

The sample studied shows that longer times on ventilation resulted in the longer times in the ICU and hospital. The same relationship has already been identified in study, which contributed to maximize patient suffering due to clinical complications during the postoperative period ${ }^{(3)}$.

A study undertaken by practice based on evidence, with the objective of relating the experience of ventilator weaning by nurses in a large scale hospital, suggested the development of protocols regarding nursing conduct during ventilator weaning in the postoperative period of cardiac surgery. Their aim was to improve the quality of the weaning process from MV and also to contribute to a quicker removal of ETT ${ }^{(12)}$.

For the practice of intensive nursing, it has become important to better understand the possible complications related to the length of time on mechanic ventilation in the postoperative period of cardiac surgery. This will help in the adoption of interventions which can avoid or reduce these complications, and provide a substantial basis on which to take decisions regarding the best moment for extubation together with the multi-professional team. These actions benefit the patient - quicker recovery, and the institution reduction in costs and human resources, allowing a greater patient turn over and so making more beds available for intensive care. 
This study has limitations: being retrospective and depending on notes from medical records. Data that could corroborate the interpretations of the presented results were not found, such as: functional capacity pre-surgery, severity score and surgery risk score. It is still not possible to infer if a longer time on MV was a predictor or consequence of some complications.

We should take into consideration the fact that the researched institution didn't indicate an ideal time for surgery patient's extubation, what could result in a longer time with the endotracheal tube.

\section{CONCLUSION}

Our results show that significantly associated significantly with increased time of ETT, are the facts of: age, chronic obstructive pulmonary disease, systemic arterial hypertension, chronic renal failure and time in CPB, continuous or intermittent use of sedatives and analgesics drugs, use of vasoconstrictor drugs, time of stay with drain tubes and the volume of the drainage in the 1st hour after surgery, and complications: acute renal failure, atelectasis, pneumonia associated with MV, sepsis, metabolic acidosis, encephalopathy caused by CPB and the sum of the comorbities and complications.

The time of stay on MV also presented correlations with longer times in ICU and hospital. Therefore, it is necessary for new studies with larger samples and prospective data to be undertaken to add to our understanding on this theme, contributing to better nursing care in the postoperative period of cardiac surgery since the professional participates actively in the whole process of assistance.

\section{REFERENCES}

1. Renault JA, Costa-Val R, Rossetti MB. Fisioterapia respiratória na disfunção pulmonar pós-cirurgia cardíaca. Rev Bras Cir Cardiovasc. 2008;23(4):562-9.

2. Laizo A, Delgado FEF, Rocha GM. Complicações que aumentam o tempo de permanência na unidade de terapia intensiva na cirurgia cardíaca. Rev Bras Cir Cardiovasc. 2010;25(2):166-71.

3. Silva, GJP, Moraes ACL, Passos JK, Lopes Filho MJA, Ribeiro Júnior JHN, Pereira Filho JVF. Estudo da prevalência de complicações pulmonares no pós-operatório de cirurgias cardíacas [resumo]. Rev Bras Fisioter. 2010;14(Suppl. I):P346.

4. Soares GMT, Ferreira DCS, Gonçalves MPC, Alves TGS, David FL, Henriques KMC, et al. Prevalência das principais complicações pós-operatórias em cirurgias cardíacas. Rev Bras Cardiol. 2011;24(3):139-46.

\section{Author's address:}

Laura Fonseca

Rua São Manoel, 963, Rio Branco

90620-110, Porto Alegre, RS

E-mail: fonseca-laura@hotmail.com
5. Arcêncio L, Souza MD, Bortolin BS, Fernandes ACM, Rodrigues AJ, Evora PRB, et al. Cuidados pré e pós-operatórios em cirurgia cardiotorácica: uma abordagem fisioterapêutica. Rev Bras Cir Cardiovasc. 2008;23(3):400-10.

6. Cislaghi F, Condemi AM, Corona A. Predictors of prolonged mechanical ventilation in a cohort of 5123 cardiac surgical patients [resume]. Eur J Anaesthesiol. 2009;25(5):396-403.

7. Goldwasser R, Farias A, Freitas EE, Saddy F, Amado V, Okamoto V. Desmame e interrupção da ventilação mecânica. J Bras Pneumol. 2007;33(Supl. II):S128-36.

8. Fonseca L, Azzolin KO. Fatores relacionados ao retardo da extubação no pós-operatório de cirurgia cardíaca [monografia]. Porto Alegre (RS): Escola de Enfermagem, Universidade Federal do Rio Grande do Sul; 2013.

9. Oliveira MM, Robles IIS, Oliveira LM, Garcia PA. Análise comparativa do tempo de internação e do tempo de uso da ventilação mecânica entre idosos e adultos jovens. Rev Movimenta. 2010;3(4):168-74.

10. Cadore MP, Guaragna JCVC, Anacker JFA, Albuquerque LC, Bodanese LC, Piccoli JCE, et al. Proposição de um escore de risco cirúrgico em pacientes submetidos à cirurgia de revascularização miocárdica. Rev Bras Cir Cardiovasc. 2010;25(4):447-56.

11. Torrati FG, Dantas RAS. Circulação extracorpórea e complicações no período pós-operatório imediato de cirurgias cardíacas. Acta Paul Enferm. 2012;25(3):3405.

12. Bráz MR, Leite JL, Dantas CC, Stipp MAC, Tyrrell MAR. Atualização em desmame ventilatório no pós-operatório de cirurgia cardíaca: a prática de enfermagem baseada em evidências. Enfermería Global. 2005;4(6):1-12.

13. Werlang SC, Azzolin K, Moraes MA, Souza EN. Comunicação não verbal do paciente submetido à cirurgia cardíaca: do acordar da anestesia à extubação. Rev Gaúcha Enferm. 2008;29(4):551-6.

14. Dixon B, Santamaria JD, Reid D, Collins M, Rechnitzer T, Newcomb AN, et al. The association of blood transfusion with mortality after cardiac surgery: cause or confounding? Transfusion. 2013;53(1):19-27.

15. Brito DJA, Nina VJS, Nina RVAH, Figueiredo Neto JA, Oliveira MIG, Salgado JVL, et al. Prevalência e fatores de risco para insuficiência renal aguda no pós-operatório de revascularização do miocárdio. Rev Bras Cir Cardiovasc. 2009;24(3):297-304.

16. Oliveira DC, Oliveira Filho JB, Silva RF, Moura SS, Silva DJ, Egito EST, et al. Sepse no pós-operatório de cirurgia cardíaca: descrição do problema. Arq Bras Cardiol. 2010;94(3):352-6.

17. Pontes SRS, Salazar RM, Torres OJM. Avaliação perioperatória de pacientes em unidade de terapia intensiva. Rev Col Bras Cir. 2013;40(2):92-7.

18. Barbosa MBG, Alves CAD, Queiroz Filho H. Avaliação da acidose metabólica em pacientes graves: método de Steward-Fencl-Figge versus a abordagem tradicional de Henderson-Hasselbalch. Rev Bras Ter Intensiva. 2006;18(4):380-4.

19. Nina VJS, Rocha MIA, Rodrigues, RF, Oliveira, VC, Teixeira JLL, Figueredo ED, et al. Avaliação escore CABDEAL como preditor de disfunção neurológica no pós-operatório de revascularização miocárdico com circulação extracorpórea. Rev Bras Cir Cardiovasc. 2012;27(3):29-35.

20. Gangopadhyay S, Acharjee A, Nayak SK, Dawn S, Piplai G, Gupta K. Immediate extubation versus standard postoperative ventilation: our experience in on pump open heart surgery. Indian J Anaesth. 2010;54(6):525-30.

Received: 20.01.2014

Approved: 07.05.2014 